\title{
PHOSPHITE AS PHOSPHORUS SOURCE TO GRAIN YIELD OF COMMON BEAN PLANTS GROWN IN SOILS UNDER LOW OR ADEQUATE PHOSPHATE AVAILABILITY
}

\author{
Fosfito como fonte de fósforo para produção de grãos em feijoeiro cultivado \\ em solos sob baixa ou adequada disponibilidade de fosfato
}

\author{
Fabricio William Ávila1, Valdemar Faquin², Douglas Ramos Guelfi Silva², \\ Carla Elisa Alves Bastos ${ }^{3}$, Nilma Portela Oliveira², Danilo Araújo Soares ${ }^{2}$
}

\begin{abstract}
The effects of foliar and soil applied phosphite on grain yield in common bean (Phaseolus vulgaris L.) grown in a weathered soil under low and adequate phosphate availability were evaluated. In the first experiment, treatments were composed of a $2 \times 7+2$ factorial scheme, with 2 soil P levels supplied as phosphate (40 e $200 \mathrm{mg} \mathrm{P} \mathrm{dm}^{-3}$ soil), 7 soil P levels supplied as phosphite (0-100 $\mathrm{mg} \mathrm{P} \mathrm{dm}{ }^{-3}$ soil), and 2 additional treatments (without $\mathrm{P}$ supply in soil, and all $\mathrm{P}$ supplied as phosphite). In the second experiment, treatments were composed of a $2 \times 3 \times 2$ factorial scheme, with 2 soil phosphate levels ( 40 e $200 \mathrm{mg} \mathrm{P} \mathrm{dm}^{-3}$ soil), combined with 3 nutrient sources applied via foliar sprays (potassium phosphite, potassium phosphate, and potassium chloride as a control), and 2 foliar application numbers (single and two application). Additional treatments showed that phosphite is not P source for common bean nutrition. Phosphite supply in soil increased the P content in shoot (at full physiological maturity stage) and grains, but at the same time considerably decreased grain yield, regardless of the soil phosphate availability. Foliar sprays of phosphite decreased grain yield in plants grown under low soil phosphate availability, but no effect was observed in plants grown under adequate soil phosphate availability. In general, foliar sprays of phosphate did not satisfactorily improve grain yield of the common bean plants grown under low soil phosphate availability.
\end{abstract}

Index terms: Phaseolus vulgaris, tropical soil, foliar fertilizer, plant nutrition.

\section{RESUMO}

Os efeitos de fosfito aplicado via solo ou foliar sobre produção de grãos em feijoeiro (Phaseolus vulgaris L.), cultivado em um solo intemperizado sob baixa ou adequada disponibilidade de fosfato foram avaliados. No primeiro experimento, o delineamento consistiu de um esquema fatorial $2 \times 7+2$, sendo 2 doses de $\mathrm{P}$ fornecidas na forma de fosfato $\left(40 \mathrm{e} 200 \mathrm{mg} \mathrm{P}^{-3} \mathrm{de}^{-3}\right.$ solo) $\mathrm{x} 7 \mathrm{doses}$ de $\mathrm{P}$ no solo fornecidas na forma de fosfito $\left(0-100 \mathrm{mg} \mathrm{P} \mathrm{dm}^{-3} \mathrm{de}\right.$ solo), mais 2 tratamentos adicionais (sem fornecimento de $\mathrm{P}$ no solo, e todo o P fornecido na forma de fosfito). No segundo experimento, o delineamento consistiu de um esquema fatorial $2 \times 3 \times 2$, com 2 doses de $\mathrm{P}$ no solo na forma de fosfato ( 40 e $200 \mathrm{mg} \mathrm{P} \mathrm{dm}^{-3}$ de solo), combinados com 3 fontes de nutrientes aplicados via pulverização foliar (fosfito de potássio, fosfato de potássio, e cloreto de potássio como um controle), e 2 números de aplicações foliares (uma e duas aplicações). Os tratamentos adicionais evidenciaram que o fosfito não é uma fonte de P para a nutrição do feijoeiro. O fornecimento de fosfito no solo aumentou o teor de P na parte aérea (no estágio de maturidade fisiológica) e nos grãos, mas, ao mesmo tempo, consideravelmente reduziu a produção de grãos, independentemente da disponibilidade de fosfato no solo. As pulverizações foliares de fosfito diminuiram a produção de grãos em plantas cultivadas com baixa disponibilidade de fosfato no solo, mas esse efeito não foi observado em plantas cultivadas com adequada disponibilidade de fosfato no solo. Em geral, as pulverizações foliares de fosfato não supriram adequadamente as necessidades de $\mathrm{P}$ pelo feijoeiro.

Termos para indexação: Phaseolus vulgaris, solo tropical, fertilizante foliar, nutrição vegetal.

(Received in august 16, 2012 and approved in october 10, 2012)

\section{INTRODUCTION}

Subtropical and tropical regions of the word often exhibit highly weathered soils (e.g. Typic Haplustox) that are characterized by low natural fertility, especially by phosphorus $(\mathrm{P})$ deprivation to plant nutrition. Phosphate anion $\left(\mathrm{H}_{2} \mathrm{PO}_{4}^{-}, \mathrm{HPO}_{4}^{2-}\right.$ and $\left.\mathrm{PO}_{4}^{3-}\right)$ is major $\mathrm{P}$ form metabolized by plants for their adequate growth and development
(NOVAIS; SMYTH, 1999; TICCONI et al., 2001), while phosphite anion $\left(\mathrm{H}_{2} \mathrm{PO}_{3}{ }^{-}\right.$and $\left.\mathrm{HPO}_{3}{ }^{2-}\right)$ is used as fungicide to control some important plant diseases, such as Phytophthora sp (DELIOPOULOS et al., 2010).

Nevertheless, besides fungicide, recently phosphite-based products also have been marketed as fertilizers for foliar spray, fertigation and direct soil

\footnotetext{
1Universidade Federal de Lavras/UFLA - Departamento de Ciência do Solo/DCS - Cx. P. 3037 - 37200-000 - Lavras - MG - Brasil fabriciowilliamavila@yahoo.com.br

${ }^{2}$ Universidade Federal de Lavras/UFLA - Departamento de Ciência do Solo/DCS - Lavras - MG - Brasil

3Universidade de São Paulo/USP - Escola Superior de Agricultura Luiz de Queiroz/ESALQ - Departamento de Ciência do Solo - Piracicaba - SP - Brasil
} 
application (THAO; YAMAKAWA, 2009). Phosphite salts are marketed as fertilizer because they contain a cation that may be plant nutrient, such as $\mathrm{K}^{+}, \mathrm{NH}_{4}^{+}, \mathrm{Ca}^{2+}, \mathrm{Mg}^{2+}$, $\mathrm{Cu}^{2+}$ or $\mathrm{Zn}^{2+}$, and often phosphite also is recommended as additional source of P for plant nutrition (ÁVILA et al., 2012a). But, phosphite effects on P nutrition of the crops still are inconclusive. It was reported that supply of phosphite improved avocado yield (LOAVATT, 1990a), and restored normal growth in phosphate-deficient citrus (LOVATT, 1990b). Others authors also mentioned beneficial effects of phosphite on yield and $\mathrm{P}$ nutrition in some crops (ALBRIGO, 1999; RICKARD, 2000). In contrast, the literature also shows that phosphite anion does not replace phosphate anion in P nutrition of the plants (THAO; YAMAKAWA, 2009), and still some works indicated that phosphite supply may cause growth depression in phosphate-deficient plants (SCHROETTER et al., 2006; THAO et al., 2008; THAO et al., 2009; ÁVILA et al., 2011; ZAMBROSI et al., 2011). However, most of the studies that evaluated the effects of phosphite anion on plant $\mathrm{P}$ nutrition were related to Arabidopsis, vegetables, seedlings, and some citrus and cereals; but there is still little knowledge about effects of phosphite on leguminous grain yield.

Common bean (Phaseolus vulgaris L.) is the most important leguminous crop in many subtropical and tropical regions of the world (GRAHAM; RANALLI, 1997; BROUGHTON et al., 2003). Previously, it was shown the effects of phosphite on growth and nutrition of common bean plants at flowering stage (ÁVILA et al., 2012a, b). In this study, the aim was to evaluate the effects of foliar and soil applied phosphite on grain yield in common bean plants grown in a weathered soil under low and adequate phosphate availability.

\section{MATERIAL AND METHODS}

The study was carried out at the Soil Science Department of the Federal University of Lavras (Lavras city, Minas Gerais State, Brazil) using samples of a lowfertility soil classified as Typic Haplustox (SOIL SURVEY STAFF, 1999) or sandy loam dystrophic Red-Yellow Latosol (EMBRAPA, 2006). Surface soil (0-20 cm depth) was collected from a non-cultivated field with natural Brazilian Cerrado vegetation. Later, after sieving through 4-mm mesh sieve, soil subsamples were characterized chemically, physically and mineralogically (Table 1), using the same methodology described in Souza et al. (2011).

Posteriorly, soil samples were transferred into plastic pots ( $6 \mathrm{dm}^{3}$ of soil per pot), and then mixed with $\mathrm{CaCO}_{3}$ and $\mathrm{MgO}$ (stoichiometric ratio of $\mathrm{Ca}: \mathrm{Mg}=4: 1$ ) to raise soil base saturation to $60 \%$ of cation exchange capacity at $\mathrm{pH}$ 7.0. After 30 days of incubation of the soil, two independent greenhouse experiments with common bean (Phaseolus vulgaris L.) cv. Radiante BRS were simultaneously carried out in a completely randomized design with three replications. Each experimental unit consisted of one pot containing two common bean plants, and all measured variables were expressed as mean of two plants.

Table 1 - Chemical, physical and mineralogical attributes of the soil (Typic Haplustox) samples, prior to treatments.

\begin{tabular}{|c|c|c|c|c|c|c|c|c|c|c|c|c|c|c|c|}
\hline \multicolumn{16}{|c|}{ Chemical $^{(1)}$} \\
\hline $\mathrm{pH}$ & $\mathrm{P}$ & $\mathrm{K}$ & $\mathrm{Zn}$ & $\mathrm{Cu}$ & $\mathrm{Mn}$ & $\mathrm{Fe}$ & \multirow{3}{*}{$\begin{array}{c}\mathrm{EP} \\
\mathrm{mg} \mathrm{L}^{-1} \\
20.5\end{array}$} & $\mathrm{Ca}$ & \multirow{2}{*}{$\begin{array}{l}\mathrm{Mg} \\
--\mathrm{cmo}\end{array}$} & \multirow{2}{*}{$\begin{array}{c}\mathrm{Al} \\
\mathrm{dm}^{-3}\end{array}$} & \multirow{2}{*}{$\begin{array}{c}\mathrm{H}+\mathrm{Al} \\
\text { soil--- }\end{array}$} & \multirow{2}{*}{$\mathrm{T}$} & $\mathrm{m}$ & $\mathrm{V}$ & \multirow{3}{*}{$\begin{array}{c}\text { MPAC } \\
\mathrm{mg} \mathrm{kg}^{-} \\
396\end{array}$} \\
\hline & --- & ------1 & $\mathrm{mg} \mathrm{dr}$ & $\mathrm{m}^{-3}$ of $\mathrm{s}$ & 1------ & ----- & & $-\mathrm{cmol}_{\mathrm{c}} \mathrm{dm}^{-3}$ of soil--- & & & & & \multicolumn{2}{|c|}{$---\%---$} & \\
\hline 5.4 & 0.9 & 22 & 0.5 & 0.7 & 0.4 & 27.4 & & 0.1 & 0.1 & 0.1 & 1.7 & 2 & 28 & 13.3 & \\
\hline \multicolumn{16}{|c|}{ Physical $^{(2)}$} \\
\hline \multicolumn{5}{|c|}{ Sand } & \multicolumn{2}{|r|}{ Silt } & & \multicolumn{4}{|c|}{ Clay } & \multicolumn{4}{|c|}{$\mathrm{OM}$} \\
\hline \multicolumn{3}{|c|}{60} & & & \multicolumn{2}{|r|}{17} & & \multicolumn{4}{|c|}{23} & \multicolumn{4}{|c|}{0.8} \\
\hline \multicolumn{16}{|c|}{ Mineralogical $^{(3)}$} \\
\hline $\mathrm{SiO}_{2}$ & & $\mathrm{Al}_{2} \mathrm{O}_{3}$ & & $\mathrm{Fe}_{2} \mathrm{O}_{3}$ & $\mathrm{TiO}$ & & $\mathrm{P}_{2} \mathrm{O}_{5}$ & $\mathrm{Fe}_{\mathrm{d}}$ & $\mathrm{Fe}_{\mathrm{o}}$ & & t & $\mathrm{Gb}$ & & $\mathrm{Ki}$ & $\mathrm{Kr}$ \\
\hline 95.1 & & 97.4 & & 36.2 & 6.2 & & 0.0 & 10.8 & 0.1 & & 2.0 & 630 & & 0.98 & 0.71 \\
\hline
\end{tabular}

(1) $\mathrm{pH}$ in water, $\mathrm{EP}=\mathrm{P}$ in the equilibrium solution; $\mathrm{OM}=$ level of organic matter; $\mathrm{T}=$ cation exchange capacity at $\mathrm{pH} 7.0 ; \mathrm{m}=$ aluminum saturation index; $\mathrm{V}=$ base saturation index; $\mathrm{MPAC}=$ maximum $\mathrm{P}$ adsorption capacity according to Olsen and Watanabe (1957); $\mathrm{Ct}=$ kaolinite; and $\mathrm{Gb}=$ gibbsite. $\mathrm{Ki}=\mathrm{SiO}_{2} / \mathrm{Al}_{2} \mathrm{O}_{3} ;$ and $\mathrm{Kr}=\mathrm{SiO}_{2} /\left(\mathrm{Al}_{2} \mathrm{O}_{3}+\mathrm{Fe}_{2} \mathrm{O}_{3}\right)$. 
In first experiment, whose aim was to evaluate the effects of phosphite application in low-fertility soil on common bean plants, treatments were composed of a $2 \times 7$ +2 factorial scheme, with 2 P levels supplied as phosphate anion (low phosphate availability $=40 \mathrm{mg} \mathrm{P} \mathrm{dm}^{-3}$ soil, and adequate phosphate availability $=200 \mathrm{mg} \mathrm{P} \mathrm{dm}^{-3}$ soil), $7 \mathrm{P}$ levels supplied as phosphite anion $(0 ; 3.125 ; 6.25 ; 12.5 ; 25$; 50 and $100 \mathrm{mg} \mathrm{P} \mathrm{dm}^{-3}$ soil), and 2 additional treatments: without supply of $\mathrm{P}$ in the soil, and all $\mathrm{P}\left(200 \mathrm{mg} \mathrm{P} \mathrm{dm}^{-3}\right.$ soil) from soil supplied as phosphite. Treatments were applied as basal dressing and then soil was homogenized, prior to sowing of the seeds. The phosphate levels (40 and $200 \mathrm{mg} \mathrm{P} \mathrm{dm}^{-3}$ soil) were selected based on the growth response of common bean in a preliminary experiment to ensure an inadequate and adequate supply of $\mathrm{P}$ for maximum plant growth. Phosphate anion was supplied as $\mathrm{KH}_{2} \mathrm{PO}_{4}$ and $\mathrm{NH}_{4} \mathrm{H}_{2} \mathrm{PO}_{4}$, and phosphite anion was supplied as $\mathrm{KH}_{2} \mathrm{PO}_{3}$ (monobasic potassium phosphite). $\mathrm{KH}_{2} \mathrm{PO}_{3}$ was obtained by the reaction of $\mathrm{H}_{3} \mathrm{PO}_{3}$ (phosphorous acid) with the $\mathrm{KOH}$. All reagents were of pa grade.

In second experiment, whose aim was to evaluate the effects of foliar application of phosphite on common bean plants, the treatments were composed of a $2 \times 3 \times 2$ factorial scheme, with 2 soil phosphate levels (low phosphate availability $=40 \mathrm{mg} \mathrm{P} \mathrm{dm}^{-3}$ soil, and adequate phosphate availability $=200 \mathrm{mg} \mathrm{P} \mathrm{dm}^{-3}$ soil), combined with 3 nutrient sources supplied via foliar application $\left(\mathrm{KH}_{2} \mathrm{PO}_{3}, \mathrm{KH}_{2} \mathrm{PO}_{4}\right.$, and $\mathrm{KCl}$ used as control of $\left.\mathrm{K}\right)$, and 2 foliar application numbers (single and two application). Single application was implemented when plants presented fourth trifoliate leaf stage, and two applications was carried out in stage of fourth trifoliate leaf and another application in the beginning flowering stage. Solutions of $\mathrm{KH}_{2} \mathrm{PO}_{3}$, $\mathrm{KH}_{2} \mathrm{PO}_{4}$ and $\mathrm{KCl}$, all of pa grade, were sprayed at concentration of $40 \mu \mathrm{M}$, using a manual backpack sprayer. Concentration of $\mathrm{P}$ equals the used dose of approximately $3 \mathrm{~L}$ of commercial potassium phosphite to $400 \mathrm{~L}$ of water, which is usually recommended for growing beans.

In both experiments, pots received application of fertilizers as basal dressing, made up of (in $\mathrm{mg} \mathrm{dm}^{-3}$ of soil): $126 \mathrm{~N}, 126 \mathrm{~K}, 40 \mathrm{~S}, 6 \mathrm{Zn}, 6 \mathrm{Mn}, 2.5 \mathrm{Cu}, 1.25 \mathrm{~B}$ and $0.25 \mathrm{Mo}$, all added as nutrient solutions that were prepared with pa grade reagents of the following: $\mathrm{KH}_{2} \mathrm{PO}_{3}(\mathrm{~K}$ added together with phosphite treatments from soil), $\mathrm{KH}_{2} \mathrm{PO}_{4}$ ( $\mathrm{K}$ added together with phosphate treatments from soil), $\mathrm{NH}_{4} \mathrm{H}_{2} \mathrm{PO}_{4}$ ( $\mathrm{N}$ added together with phosphate treatments from soil), $\mathrm{NH}_{4} \mathrm{NO}_{3},\left(\mathrm{NH}_{4}\right)_{2} \mathrm{SO}_{4}, \mathrm{KNO}_{3}, \mathrm{MnCl}_{2} \cdot 4 \mathrm{H}_{2} \mathrm{O}, \mathrm{CuSO}_{4} .5 \mathrm{H}_{2} \mathrm{O}$, $\mathrm{H}_{2} \mathrm{MoO}_{4} \cdot 2 \mathrm{H}_{2} \mathrm{O}, \mathrm{H}_{3} \mathrm{BO}_{3}$ and $\mathrm{ZnSO}_{4} \cdot 7 \mathrm{H}_{2} \mathrm{O}$. Some of these sources were combined differently for each phosphate and phosphite treatment from soil. During the experimental period, fertilization as top dressing also was supplied individually to each pot at following rates (in $\mathrm{mg} \mathrm{dm}^{-3}$ of soil): $210 \mathrm{~N}, 180 \mathrm{~K}$ and $42 \mathrm{~S}$, using solutions of $\mathrm{KNO}_{3}$, $\mathrm{NH}_{4} \mathrm{NO}_{3}$ and $\left(\mathrm{NH}_{4}\right)_{2} \mathrm{SO}_{4}$. This fertilization was split among into three applications throughout the experiment. Soil water content was maintained at around $60 \%$ of the total pore volume by periodic weighing of the pots and adding deionized water to compensate for weight loss. Common bean plants were harvested at full physiological maturity, and grains were separated from shoot. Plant shoot and grains were dried for 72 hours at $60-65^{\circ} \mathrm{C}$ in a forced draught oven, weighed (for obtaining the dry mass weight) and triturated in a Wiley-type mill. Samples of shoot and grains were analyzed for Pcontent (MURPHY; RILEY, 1962) after nitric-perchloric digestion of the plant material.

Data obtained were submitted to variance analysis by F test ( $p \leq 0.05$ ) using the SISVAR software (FERREIRA, 2011). In first experiment (application of phosphite in the soil), statistical comparisons between the additional treatments, as well as between additional treatment and factorial experiment, were evaluated according to Healy (1956).

\section{RESULTSAND DISCUSSION}

In first experiment, shoot growth (at full physiological maturity stage) and grain yield of the common bean plants were considerably affected by application of medium and high phosphite levels in the soil (Typic Haplustox) (Figure 1).

Supply of low phosphite levels in soil had little effect $(p>0.05)$ on the shoot and grain dry weight of the common bean plants grown under low and adequate phosphate supply. However, in general from medium phosphite levels ( $25 \mathrm{mg} \mathrm{P} \mathrm{dm}^{-3}$ soil), it was observed lower shoot and grain dry weight with increasing soil phosphite levels, which was exhibiting phosphite-toxicity symptoms such as both curved and malformed leaves. Values of shoot dry weight at highest phosphite level (100 $\mathrm{mg} \mathrm{P} \mathrm{dm}^{-3}$ soil), in comparison to zero phosphite level (without phosphite supply), were significantly ( $p \leq 0.001$ ) decreased by 65 and $53 \%$ for plants grown under low and adequate phosphate availability, respectively (Figure 1a). In addition, values of grain dry weight of the plants grown under adequate phosphate availability were significantly ( $p \leq 0.001$ ) 35\% lower at highest phosphite level than those at zero phosphite level, and plants grown under low phosphate availability did not produce grain at two higher phosphite levels (50 and $100 \mathrm{mg} \mathrm{P} \mathrm{dm}^{-3}$ soil), thus showing $100 \%$ of decrease of the grain yield in comparison to zero phosphite level (Figure 1b). 

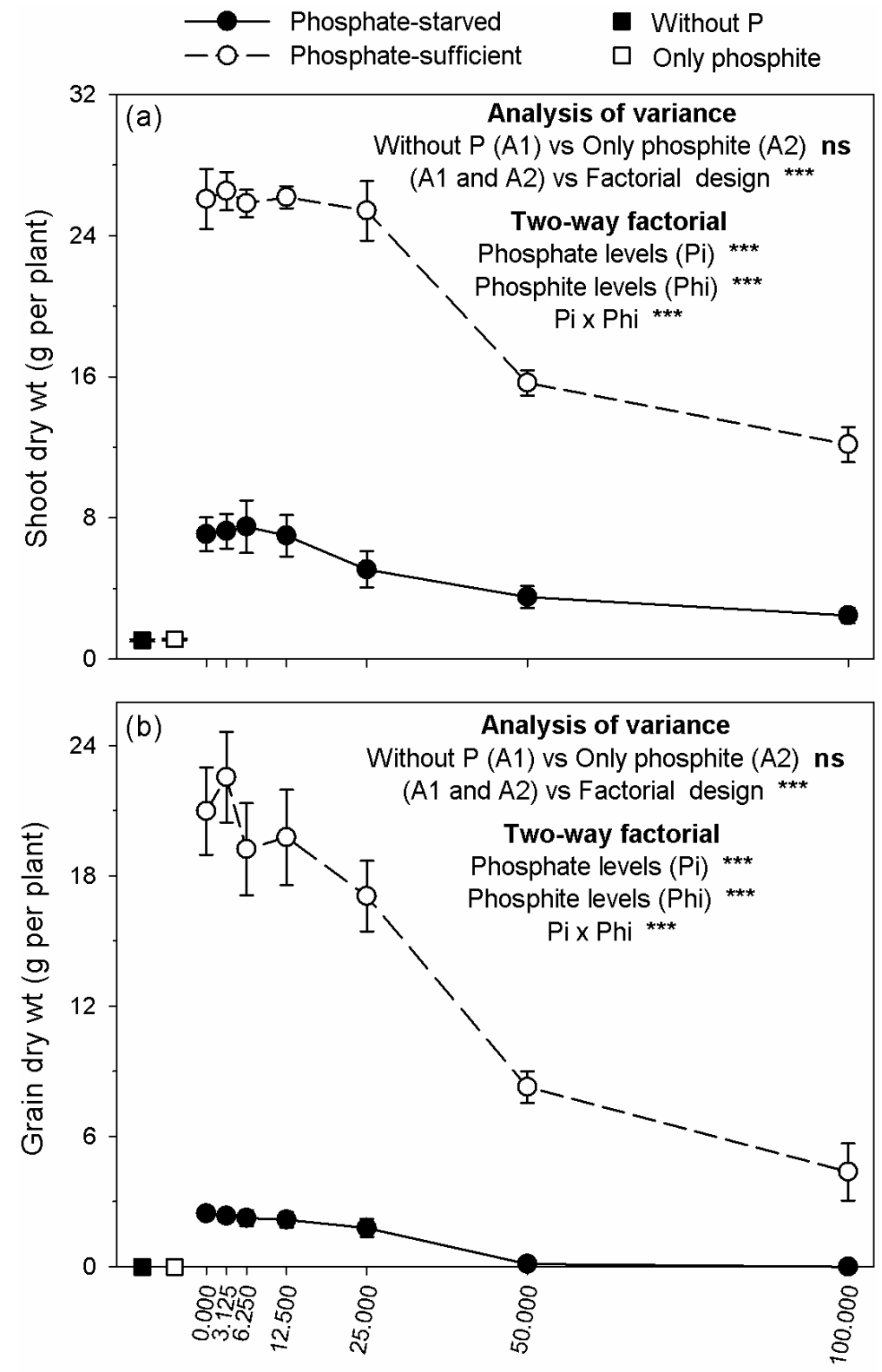

Phosphite levels in the soil ( $\mathrm{mg} \mathrm{P} \mathrm{dm} \mathrm{dm}^{-3}$ soil)

Figure 1 - Shoot dry weight (a) and grain dry weight (b) in common bean grown under 2 phosphate levels (phosphatestarved $=40 \mathrm{mg} \mathrm{Pdm}^{-3}$ soil, and phosphate-sufficient $=200 \mathrm{mg} \mathrm{Pdm}^{-3}$ soil), and 7 phosphite levels in the soil. Without $\mathrm{P}=$ without supply of $\mathrm{P}$ in the soil. Only phosphite $=$ supply of phosphite $\left(200 \mathrm{mg} \mathrm{Pdm}^{-3}\right.$ soil $)$ as source de $\mathrm{P}$. The bars represent the standard error of the mean $(n=3)$. *** and ns (non-significant) corresponding to $p \leq 0.001$ and $p>0.05$, respectively.

The literature shows that some previous studies also found harmful effects of phosphite anion on plants grown under low phosphate availability, but no harmful effects have been reported when this anion was applied in plants grown under adequate phosphate availability
(TICCONO et al., 2001; VARADARAJAN et al., 2002; LEE et al., 2005; SCHROETTER et al., 2006; DEVAIAH et al., 2007; THAO et al., 2008; MOOR et al., 2009; THAO et al., 2009; ÁVILA et al., 2011). However, most of these studies were based in Arabidopsis, vegetables, seedlings, citrus, 
and some cereals, but there is still little information on the effects of phosphite on leguminous plants, especially on grain yield of leguminous. Moreover, these works studied effects of phosphite on plants grown in soils of low phosphate sorption capacity (soils of temperate regions of the world) or in nutrient solution, and also applied phosphite via foliar spray, but studies that relate effects of phosphite on plants grown in weathered soils of tropical and subtropical regions of the world still are rare (ÁVILA et al., 2012a).

Additional treatments also affected considerably the growth (at full physiological maturity stage) and grain yield of common bean. No P supply and P supply only as phosphite (200 $\mathrm{mg} \mathrm{P} \mathrm{dm}^{-3}$ soil), decreased by $96 \%$ and $100 \%$ the weight of shoot and grains (there was not produce grains in additional treatments), in comparison to those of plants grown under adequate phosphate availability (200 $\mathrm{mg} \mathrm{P} \mathrm{dm}{ }^{-3}$ soil) and without phosphite supply (Figure 1). It was not observed significant $(p>0.05)$ difference of shoot and grain yield between the two additional treatments. Thus, data show that phosphite anion did not replace phosphate anion in P nutrition for grain yield of common bean. These results are in agreement with those reported for other crops, such as Ulva lactuca (LEE et al., 2005), maize (SCHROETTER et al., 2006; ÁVILA et al., 2011), Brassica rapa (THAO et al., 2008), citrus rootstocks (ZAMBROSI et al., 2011), and sweet potato tissue cultures (HIROSSE et al., 2012).

In second experiment, it was found that foliar spraying of phosphite affected only the shoot growth (at full physiological maturity stage) and grain yield of the common bean plants grown under low phosphate availability, while no effect was verified for common bean plants grown under adequate phosphate availability (Figure 2).
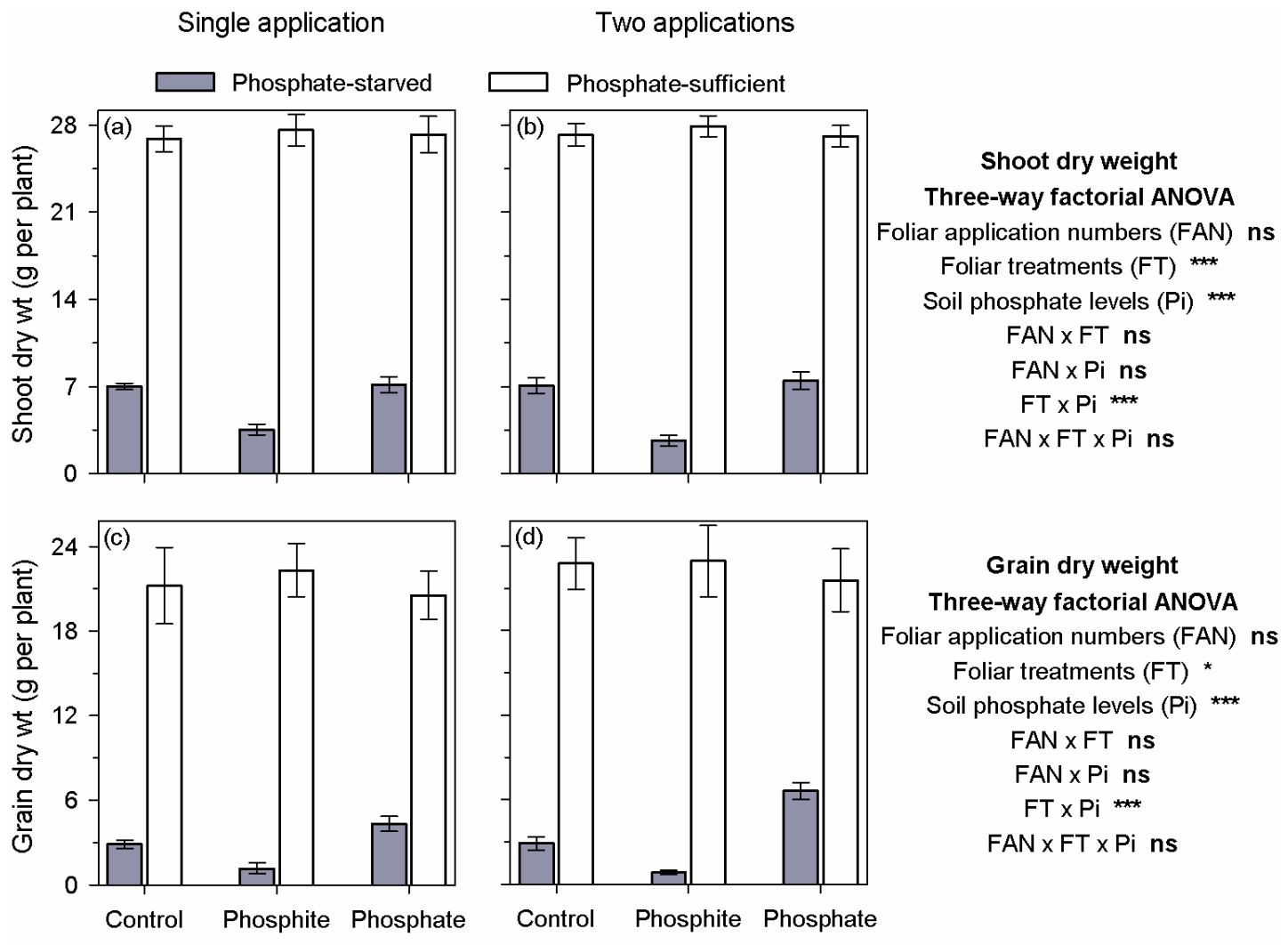

Foliar treatments

Figure 2 - Shoot dry weight (a and b) and grain dry weight (c and d) in common bean grown under 2 phosphate levels (phosphate-starved plants $=40 \mathrm{mg} \mathrm{P} \mathrm{dm}^{-3}$ soil, and phosphate-sufficient plants $=200 \mathrm{mg} \mathrm{P} \mathrm{dm}^{-3}$ soil), 3 nutrient sources supplied via foliar application (potassium chloride as a control, potassium phosphite, and potassium phosphate), and 2 foliar application numbers (single and two applications). The bars represent the standard error of the mean $(n=3)$. $* * *, *$ and ns (non-significant) corresponding to $p \leq 0.001, p \leq 0.05$ and $p>0.05$, respectively.

Ciênc. agrotec., Lavras, v. 36, n. 6, p. 639-648, nov./dez., 2012 
In comparison to control and potassium phosphate spray, regardless of foliar application numbers (single application timing and two application timings), shoot and grain dry weight was not significantly $(p>0.05)$ influenced by potassium phosphite spray when common bean plants grew under adequate phosphate availability in the soil. However, for plants grown under low phosphate availability, shoot and grain dry weight were significantly $(p<0.05)$ limited by foliar-applied phosphite.

The toxic effect of phosphite anion on plants deficient in phosphate anion also was found by others authors, as already was commented. The causes of this effect are not well understood. There is the hypothesis that plants did not metabolize phosphite anion, and this anion may suppress some plant responses to phosphate deficiency, such as synthesis of phosphatases and $\mathrm{P}$ transporters (TICCONI et al., 2001; VARADARAJAN et al., 2002; ÁVILA et al., 2011).

In relation to results from potassium phosphate spray, it was found that foliar-applied phosphate did not alter shoot growth and grain yield of the plants grown under adequate phosphate availability in the soil. However, although shoot growth was not influenced, the grain yield of the plants grown under low phosphate availability was a little higher $(p<0.05)$ with two foliar sprays of phosphate, but this increase was not sufficient to compensate the low productivity caused by phosphate deficiency in the soil. Therefore, several foliar sprays of phosphate may be necessary to adequately correct a plant P deficiency (FAQUIN, 2005); this has been economically impractical (ÁVILA et al., 2012b).

The values of $\mathrm{P}$ content in shoot (at full physiological maturity stage) and grains of the common bean plants were considerably increased from medium phosphite levels in the soil (in general from $25 \mathrm{mg} \mathrm{P} \mathrm{dm}^{-3}$ soil), regardless of the soil phosphate availability (Figure $3)$.

Shoot $\mathrm{P}$ content of the common bean plants grown under low and adequate phosphate availability was, respectively, 7- and 2-fold higher at maximum phosphite level than that at the zero phosphite level (Figure 3a). Besides the "concentration effect", caused by growth reduction of the plants (FAQUIN, 2005), this relevant increase in shoot $P$ content of the plants at the maximum phosphite level also was due to uptake of phosphite from soil by plants. Probably the common bean plants took up phosphite anion from soil, since medium and high soil phosphite levels were considerably toxic for plant growth.
This supposition is confirmed by results of shoot $\mathrm{P}$ content in additional treatments. While shoot $\mathrm{P}$ content in the first additional treatment (without supply of $\mathrm{P}$ in the soil) was much lower than that in the second additional treatment (all $\mathrm{P}$ from soil was supplied as phosphite), the shoot dry weight did not vary between both additional treatments (in this case there was not influence of "concentration effect" in shoot of plants grown in the second additional treatment), showing that common bean takes phosphite anion from soil. In agreement with this study, Thao et al. (2009) also found increase in P content of hydroponic lettuce with supply of phosphite in nutrient solution. Moreover, in this work, grain $\mathrm{P}$ content of the plants grown under adequate phosphate availability was 1.5 -fold higher at maximum phosphite level than that at zero phosphite level (Figure $3 b)$. For plants grown under low soil phosphate availability, grain $\mathrm{P}$ content at level of $25 \mathrm{mg} \mathrm{P} \mathrm{dm}^{-3}$ soil (maximum phosphite level in which there was grain yield of the deficient plants in phosphate) was 1.3-fold higher than that at the zero phosphite level.

Unlike the supply of phosphite in weathered soil, one or two foliar sprays of potassium phosphite did not influence significantly $(p>0.05) \mathrm{P}$ content in shoot (at full physiological maturity stage) and grains of the common bean plants grown under low and adequate phosphate availability in the soil, when compared with the foliar sprays of potassium chloride or phosphate (Figure 4). However, in this study, foliar sprays of phosphite reduced shoot growth and grain yield, as already was commented, showing that common bean plants taken up the foliarapplied phosphite, but there was not variation in shoot and grain $P$ content.

Foliar sprays of potassium phosphate also did not alter significantly $(p>0.05) \mathrm{P}$ content in shoot (at full physiological maturity stage) and grains of the common bean plants, regardless of the soil phosphate availability (Figure 4). These results are in agreement with those obtained by Conte e Castro and Boaretto (2001) who found that three foliar application timing of phosphate did not affect $\mathrm{P}$ content in grains of common bean grown under field conditions. Finally, in both experiments, in general plants exposed to phosphate starvation exhibited lower $\mathrm{P}$ content in shoot (at full physiological maturity stage) and grains, showing that low phosphate availability from soil decreased the P uptake by the common bean plants and, consequently, reduced their shoot growth and grain yield. 

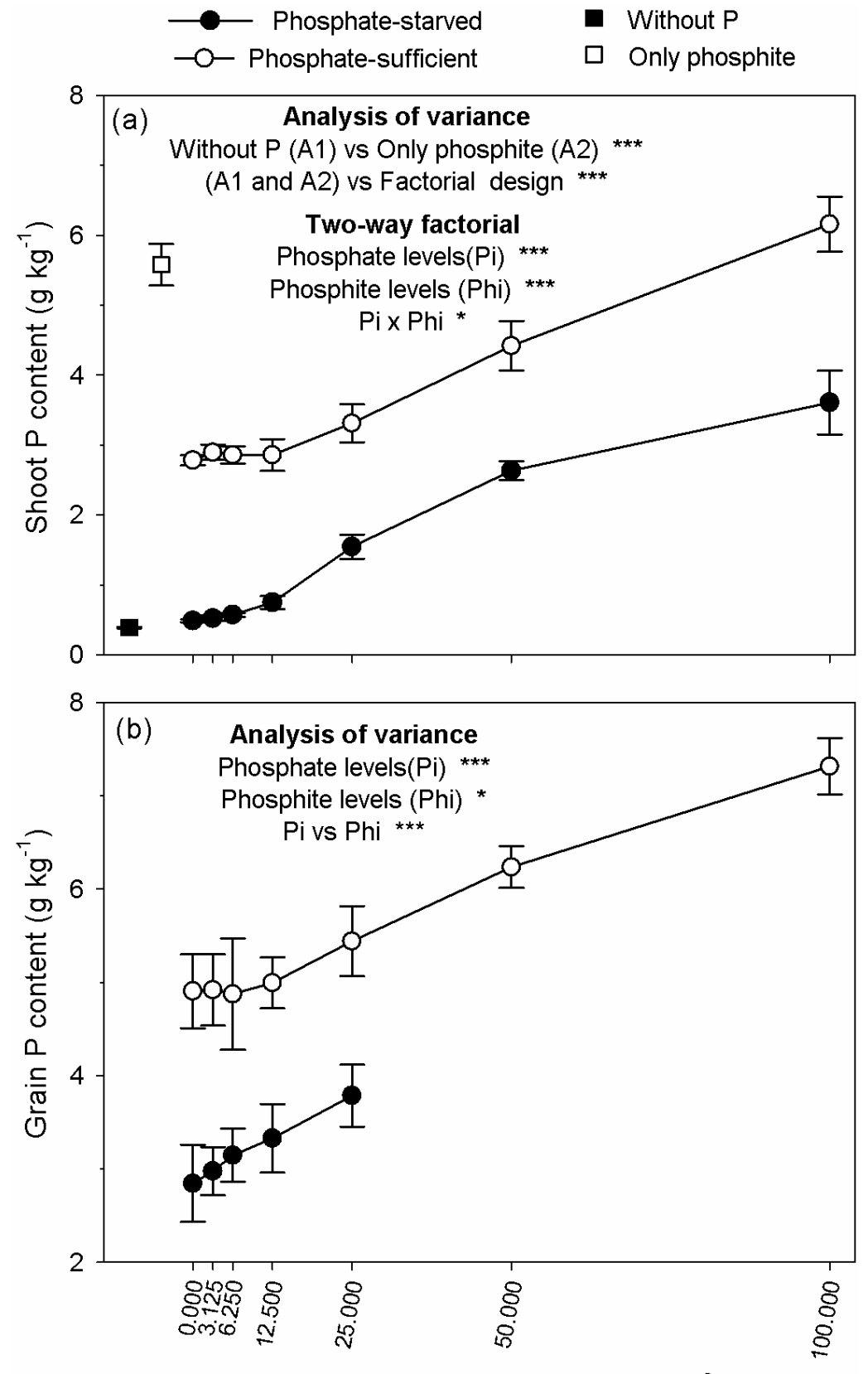

Phosphite levels in the soil ( $\mathrm{mg} \mathrm{P} \mathrm{dm}^{-3}$ soil)

Figure 3 - Shoot P content (a) and grain P content (b) in common bean grown under 2 phosphate levels (phosphatestarved plants $=40 \mathrm{mg} \mathrm{P} \mathrm{dm}^{-3}$ soil, and phosphate-sufficient plants $=200 \mathrm{mg} \mathrm{P} \mathrm{dm}^{-3}$ soil), and 7 phosphite levels in the soil. Without $\mathrm{P}=$ without supply of $\mathrm{P}$ in the soil. Only phosphite $=$ supply of phosphite $\left(200 \mathrm{mg} \mathrm{P} \mathrm{dm}^{-3}\right.$ soil $)$ as source de $\mathrm{P}$. The bars represent the standard error of the mean $(n=3)$. *** and * corresponding to $p \leq 0.001$ and $p \leq 0.05$, respectively. 


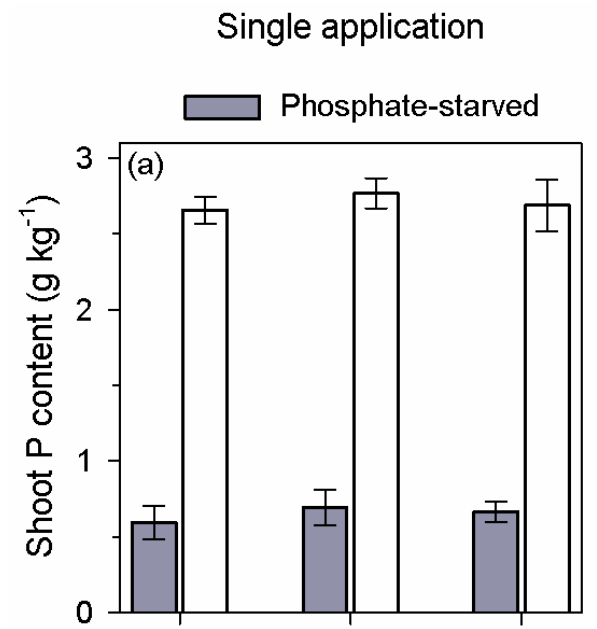

\section{Two applications}

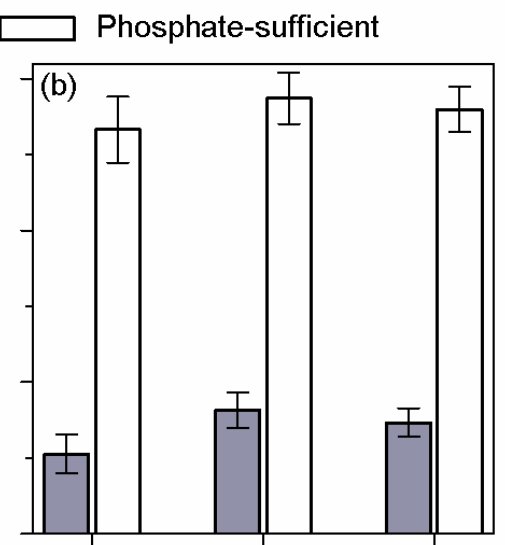

\section{Shoot P content \\ Three-way factorial ANOVA}

Foliar application numbers (FAN) ns

Foliar treatments (FT) ns

Soil phosphate levels (Pi) ***

FAN $x$ FT ns

FAN $\times$ Pi ns

FT $x$ Pi ns

FAN $\times$ FT $x$ Pi ns
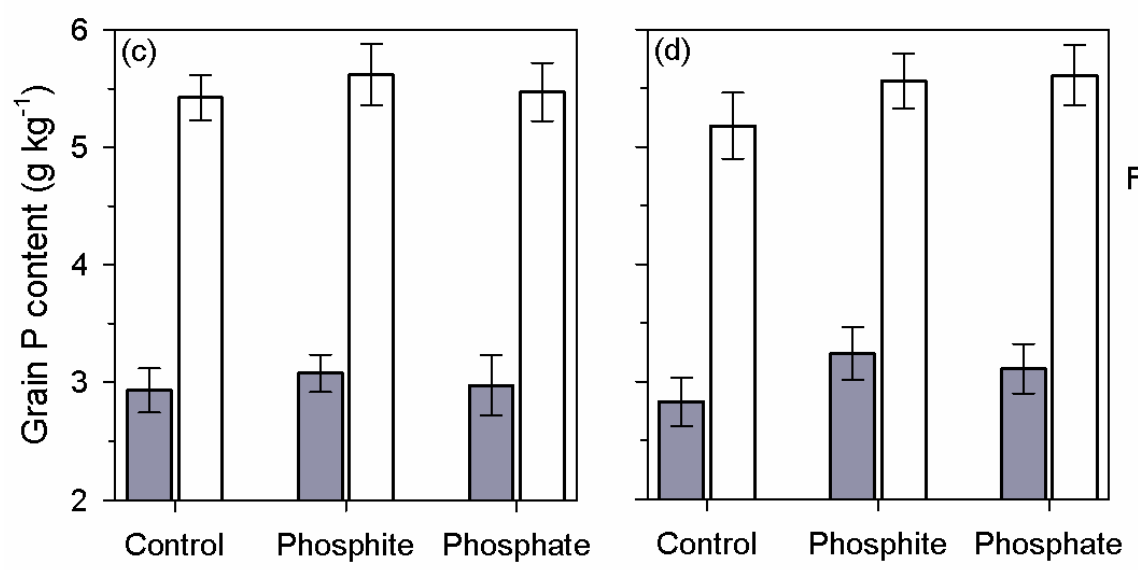

\section{Grain P content}

Three-way factorial ANOVA

Foliar application numbers (FAN) ns

Foliar treatments (FT) ns

Soil phosphate levels $(\mathrm{Pi})$ **

FAN $x$ FT ns

FAN $\times$ Pi ns

FT $x$ Pi ns

FAN $x$ FT $x$ Pi ns

Foliar treatments

Figure 4 - Shoot $\mathrm{P}$ content ( $\mathrm{a}$ and $\mathrm{b}$ ) and grain $\mathrm{P}$ content ( $\mathrm{c}$ and d) in common bean grown under 2 phosphate levels (phosphate-starved plants $=40 \mathrm{mg} \mathrm{P} \mathrm{dm}^{-3}$ soil, and phosphate-sufficient plants $=200 \mathrm{mg} \mathrm{P} \mathrm{dm}^{-3}$ soil), 3 nutrient sources supplied via foliar application (potassium chloride as a control, potassium phosphite, and potassium phosphate), and 2 foliar application numbers (single and two applications). The bars represent the standard error of the mean $(n=3)$. $* * *$ and ns (non-significant) corresponding to $p \leq 0.001$ and $p>0.05$, respectively.

\section{CONCLUSIONS}

Phosphite is not adequate $\mathrm{P}$ source to common bean crop.

Supply of medium and high phosphite levels in weathered soil decreased grain yield of common bean, regardless of soil phosphate availability.

Foliar sprays of phosphite decreased grain yield of the plants grown under low soil phosphate availability, but no effect was observed in plants grown under adequate soil phosphate availability. Thus, foliar sprays of phosphite in common bean crop to other purposes (e.g. fungicide) require adequate plant phosphate nutrition.

Either one or two foliar sprays of phosphate did not satisfactorily improve grain yield of the common bean plants grown under low soil phosphate availability.

\section{ACKNOWLEDGEMENTS}

The authors are grateful to the CNPq, CAPES and FAPEMIG, all from Brazil, for the financial support. The first author also thanks CNPq for a graduate fellowship. 


\section{REFERENCES}

ALBRIGO, L.G. Effects of foliar applications of urea or Nutriphite on flowering and yields of Valencia orange trees. Proceedings of the Florida State Horticultural Society, Tallahassee, v.112, p.1-4, 1999.

ÁVILA, F.W. et al. Phosphite supply affects phosphorus nutrition and biochemical responses in maize plants.

Australian Journal of Crop Science, Lismore, v.5, n.6, p.646-653, 2011.

ÁVILA, F.W. et al. Effects of phosphite and phosphate supply in a weathered tropical soil on biomass yield, phosphorus status and nutrient concentrations in common bean. International Journal of Food, Agriculture and Environment, Helsinki, v.10, n.2, p.312317, 2012a.

ÁVILA, F.W. et al. Growth, phosphorus status, and nutritional aspect in common bean exposed to different soil phosphate levels and foliar-applied phosphorus forms. Scientific Research and Essays, Lagos, v.7, n.25, p.2195-2204, $2012 b$.

BROUGHTON, W.J. et al. Beans (Phaseolus spp.): model food legume. Plant and Soil, Dordrecht, v.252, n.1, p.55$128,2003$.

CONTE E CASTRO, A.M.; BOARETTO, A.E. Adubação foliar do feijoeiro com nutrientes, vitamina b1 e metionina. Scientia Agraria, Curitiba, v.2, n.1, p.117-121, 2001.

DELIOPOULOS, T.; KETTLEWELL, P.S.; HARE, M.C. Fungal disease suppression by inorganic salts: A review. Crop Protection, Guildford, v.29, n.10, p.10591075, 2010.

DEVAIAH, B.N.; NAGARAJAN, V.K.; RAGHOTHAMA, K.G. Phosphate homeostasis and root development in Arabidopsis are synchronized by the zinc finger transcription factor ZAT6. Plant Physiology, Rockville, v.145, n.1, p.147-159, 2007.

\section{EMPRESA BRASILEIRA DE PESQUISA}

AGROPECUÁRIA - EMBRAPA. Centro Nacional de Pesquisas de Solos. Sistema brasileiro de classificação de solos. 2. ed. Rio de Janeiro, Embrapa Solos, 2006. $306 \mathrm{p}$.
FAQUIN, V. Nutrição mineral de plantas. Lavras: UFLA/ FAEPE, 2005. 182p.

FERREIRA, D.F. Sisvar: a computer statistical analysis system. Ciência e Agrotecnologia, Lavras, v.35, n.6, p.1039-1042, nov./dez. 2011.

GRAHAM, P.H.; RANALLI, P. Common bean (Phaseolus vulgaris L.). Field Crops Research, Amsterdam, v.53, n.1-3, p.131-146, 1997.

HEALY, M.J.R. The analysis of a factorial experiment with additional treatments. Journal of Agricultural Science, Cambridge, v.47, n.2, p.205-206, 1956.

HIROSSE, E.H. et al. In vitro growth of sweet potato fed with potassium phosphite. Acta Scientiarum. Agronomy, Maringá, v.34, n.1, p.85-91, Jan./Mar. 2012 .

LEE, T.M. et al. The effects of phosphite on phosphate starvation responses of Ulva lactuca (Ulvales, chlorophyta). Journal of phycology, Lawrence, v.41, n., p.975-982, 2005.

LOVATT, CJ. A definitive test to determine whether phosphite fertilization can replace phosphate fertilization to supply P in the metabolism of 'Hass' on 'Duke 7'. California Avocado Society Yearbook, Temecula, v.74, p.61-64, 1990a.

LOVATT CJ. Foliar phosphorus fertilization of citrus by foliar application of phosphite. In: Citrus Research Advisory Committee (Ed). Summary of Citrus

Research. Riverside, CA: University of California, 1990b. p.25-26.

MOOR, U. et al. Effect of phosphite fertilization on growth, yield and fruit composition of strawberries. Scientia Horticulturae, Amsterdam, v.119, n.3, p.264269, Feb. 2009.

MURPHY, J.; RILEY, H.P. A modified single solution method for the determination of phosphate in natural waters. Analytica Chimica Acta, Amsterdam, v.27, n.1, p.31-36, 1962.

NOVAIS, R.F.; SMITH, T.J. Fósforo em solo e planta em condições tropicais. Viçosa, MG: DPS/UFV, 1999. $399 \mathrm{p}$. 
OLSEN, S.R.; WATANABE, F.S. A method to determine a phosphorus adsorption maximum of soils as measured by the Langmuir Isotherm. Soil Science Society of America Journal, Madison, v.21, n.2, p.144149, 1957.

RICKARD, D.A. Review of phosphorus acid and its salts as fertilizer materials. Journal of Plant Nutrition, New York, v.23, n.2, p.161-180, 2000.

SCHRÖETTER, S. et al. Effects of phosphite on phosphorus suplly and growth of corn (Zea mays). Landbauforschung Volkenrodxe. Fal Agricultural Research, Braunschweig, v.56, n.3-4, p.87-99, Sept. 2006.

SOIL SURVEY STAFF. Soil taxonomy: a basic system of soil classification for making and interpreting soil surveys. 2.ed. Washington: US Department of Agriculture, 1999. 869p.

SOUZA, R.F.de et al. Carbonate-silicate ratio for soil correction and influence on nutrition, biomass production and quality of palisade grass. Scientia Agrícola, Piracicaba, v.68, n.5, p.526-534, Sept./Oct. 2011.

THAO, H.T.B. et al. Growth response of komatsuma (Brassica rapa var. peruvirids) to root and foliar applications of phosphate. Plant and Soil, Dordrecht, v.308, n.1-2, p.1-10, July 2008.

THAO, H.T.B.; YAMAKAWA, T. Phosphite (phosphorous acid): Fungicide, fertilizer or biostimulator? Soil Science and Plant Nutrition, Tokyo, v.55, n.2, p.228-234, 2009.

THAO, H.T.B.; YAMAKAWA, T.; SHIBATA, K. Effect of phosphite-phosphate interaction on growth and quality of hydroponic lettuce (Lactuca sativa L.). Journal of Plant Nutrition and Soil Science, Weinheim, v.172, n.3, p.378-384, 2009.

TICCONI, C.A.; DELATORRE, C.A.; ABEL, S. Attenuation of phosphate starvation responses by phosphite in Arabidopsis. Plant Physiology, Rockville, v.127, n.3, p.963-972, Nov. 2001.

VARADARAJAN, D.K. et al. Phosphite, an analog of phosphate suppresses the coordinated expression of genes under phosphate starvation. Plant Physiology, Rockville, v.129, n.3, p.1232-1240, July 2002.

ZAMBROSI, F.C.B.; MATTOS JR., D.; SYVERTSEN, J.P. Plant growth, leaf photosynthesis, and nutrient-use efficiency of citrus rootstocks decrease with phosphite supply. Journal of Plant Nutrition and Soil Science, Weinheim, v.174, n.3, p.487-495, 2011. 